\title{
European integration and the political economy of inequality
}

European Union Politics 2015, Vol. 16(4) 536-557 (C) The Author(s) 2015 Reprints and permissions: sagepub.co.uk/journalsPermissions.nav DOI: $10.1177 / 1465116515591832$ eup.sagepub.com

\section{Marius R Busemeyer}

University of Konstanz, Germany

\section{Tobias Tober}

University of Konstanz, Germany

\begin{abstract}
This study examines the role of European integration as a potential source of income inequality in countries of the European Union. We distinguish between both economic and political integration and identify theoretical mechanisms that link the two to rising levels of inequality. The empirical analysis draws on time-series-cross-section data covering 14 European Union member states for the time period 1999-2010. In particular, we make use of a newly available dataset that measures individual degrees of integration across different dimensions. Our main finding is a positive association between political integration and inequality on the one hand as well as a nonassociation between economic integration and inequality on the other hand. This suggests that the recent trend toward inequality at the European Union national level is at least partly related to deepening political integration at the supranational level.
\end{abstract}

\section{Keywords}

European integration, inequality, European Union member states, political economy, cross-sectional time-series

\section{Introduction}

In current public and academic discourse, only few issues are as salient as income inequality and its consequences. Although many empirical studies find evidence of growing economic inequality in Western democracies (e.g. Smeeding, 2005), the debate about its proximate and ultimate causes is still ongoing. A plausible and

\section{Corresponding author:}

Tobias Tober, Department of Politics and Public Administration, University of Konstanz, Universitätsstraße I0, Konstanz D-78464, Germany.

Email: tobias.tober@uni-konstanz.de 
often mentioned explanation links the rise in inequality to the progressing trend of globalization (see, for instance, Dreher and Gaston, 2008; Mahler, 2004). However, even though this line of reasoning is well theorized, the majority of research has failed to provide conclusive findings (Scheve and Slaughter, 2004: 662).

Beckfield $(2005,2006,2009)$ concludes from the lack of evidence that social scientists have looked at the wrong place: In his view, globalization may not be the main driver of rising inequality, but rather regional integration, in particular the process of economic and political integration in the member countries of the European Union (EU). There are two major reasons for why European integration could be more important than globalization as such. First, the economic conditions and processes that globalization theories identify could be more intense within the EU than in the global economy as a whole. This might be the case because the creation of the Single Market has led to a higher degree of economic integration between the EU member states as compared to the rest of the world. Of course, the process of economic globalization and European economic integration are related to each other and their effects are hard to disentangle empirically. However, different from globalization at large, European economic integration is also promoted actively through a process of political integration, the second reason why Europeanization could be related to increasing inequality. Many scholars have pointed out that the European integration process is biased in favor of economic interests and neglects the social policy dimension (Kosonen, 1995; Martin, 2004; Martin and Ross, 2004b; Pollack, 2005; Scharpf, 1996, 1999, 2002). Building on this literature, we propose two causal mechanisms (institutional membership and compliance with EU law) that might link political integration with higher levels of inequality.

In essence, we want to analyze the extent to which economic integration (the first of the two potential drivers) and political integration (the second) contribute to the trend of rising inequality. For that reason, we make use of a newly available dataset that provides multidimensional measures of the different degrees of European integration. It includes 14 EU member states annually observed between 1999 and 2010. These data allow us to test the explanatory power of various theories of globalization and European integration. To our knowledge - with the exception of the cited work by Beckfield (2005, 2006, 2009) - there is not yet any study on how differences in European integration are related to differences in inequality. Applying a fixed-effects strategy, we find evidence for a positive and statistically significant association between differences in European political integration and income inequality. At the same time, we do not find robust evidence for a similar effect of economic integration.

\section{European integration and economic inequality}

In this section, we develop a set of hypotheses for why (changes in) European integration might explain changes in inequality. Following the idea that European integration has an economic and a political dimension, we structure 
the hypotheses accordingly. Prior to this, we give a brief overview of the literature on European integration on the one hand and inequality on the other hand.

\section{Literature review}

Different attempts have been made to measure the total extent of European integration (e.g. Leuffen et al., 2012), but few are specifically concerned with measuring differences in the individual extent of integration across countries. In general terms, an examination of differing degrees of European integration should at least include a political and an economic dimension (Caporaso, 1976: 348; Scharpf, 1999: 44). The political dimension would have to measure institutional elements such as structures of supranational governance as well as the extent of coordination and integration in policymaking aiming at the formation of a political union. The economic dimension would have to capture market integration, which can be achieved through the removal of tariffs or the free movement of services and production factors (Beckfield, 2005).

Most of the existing literature in this field is concerned with explaining differences in European integration and less with studying the consequences of differentiated integration on policy output and socioeconomic outcomes such as inequality. Vice versa, the comprehensive literature on the political economy of inequality has largely ignored the potential role that European integration might play. The majority of contributions is concerned with assessing the impact of domestic forces such as partisan politics or power resources of the working class (Bradley et al., 2003; Pontusson et al., 2002), electoral institutions (Iversen and Soskice, 2006, 2009), or the institutional setup of the economy, especially the wage-bargaining system (Rueda and Pontusson, 2000; Wallerstein, 1999). More recently, the education and training system has been found to play an important role as well (Busemeyer, 2015; Solga, 2014). Some studies, mostly in labor economics and sociology, focused on the relationship between inequality and globalization more broadly defined, but the evidence is mixed (e.g. Dreher and Gaston, 2008; Mahler, 2004).

\section{Economic integration}

The pertinent literature on economic globalization identifies a number of mechanisms by which economic integration could contribute to higher levels of inequality. For instance, increased wage competition between employees, resulting in a loss of bargaining power on the part of unions, together with a potential 'race to the bottom' between member states in taxes and public spending could eventually lead to higher levels of inequality. In principle, the logic behind these mechanisms can be extended to European integration because there are indeed good reasons to believe that their impact on inequality may be particularly strong in the regional context. In many ways, economic integration within the EU can be regarded as a more intensive version of economic integration as it plays out in the global economy. Although we will not be able to differentiate precisely between these mechanisms in the empirical section due to data limitations, we will discuss them in detail in the following. 
The more economically integrated a member state is, the more open is its economy for intra-regional trade. It is plausible to expect that employers in an open economy would be more likely to dismiss their employees in response to higher wage demands than in a closed economy. The Single Market of the EU, 'in which the free movement of goods, capital, services, and people is ensured and in which European citizens are free to live, work, study, and do business' (European Union, 2013), has created a huge labor pool and has opened up new opportunities for investment in other European countries. Thus, domestic workers can be more easily substituted by foreign labor and nonlabor factors of production.

Closely related to these arguments is the view that economic integration decreases the bargaining power of organized workers (cf. Dreher and Gaston, 2008). Both growing competition across borders as well as the increased price elasticity of labor demand can be seen as a direct weakening of unions' market power. Furthermore, capital is more mobile than labor within the borders of the internal market (Streeck and Schmitter, 1991) and therefore unions are faced with the permanent threat of exit of employers, for instance in the form of offshoring. In the presence of these risks, "unions find themselves compelled to accept lower wages or less attractive employment conditions in order to save existing jobs' (Scharpf, 2002: 649). Since labor unions have increasingly lost influence in the process of collective bargaining, benefits of union membership have also declined and as a consequence union membership itself is expected to decline further (cf. Dreher and Gaston, 2007). Decreasing levels of union membership in turn may lead to rising levels of economic inequality (e.g. Alderson and Nielsen, 2002). Furthermore, Streeck and Schmitter (1991) argue that organized workers' weakness at the national level will not be compensated at the European level. The authors explain this claim by the fact that unions are mainly organized nationally and capital opposes any kind of EU-centered redistributive collective bargaining in order not to lose competitive advantages.

Economic integration also has far-reaching implications for the capacity of national governments to regulate and tax mobile factors of production. The loss of control over national boundaries and the decrease in costs for transnational transportation and communication made it possible for both corporations as well as investors to avoid countries with a high tax burden and cumbersome regulation (Scharpf, 1999). Even if mobile factors do not actually make use of the exit option, member states may still feel forced to engage in regulatory competition with each other in order to maintain or attract capital (Scharpf, 1999). Workers, however, may still demand compensation for the risks they face in a more competitive working environment in the form of social policies (cf. Burgoon, 2009), but governments may be less able to deliver in terms of higher spending (Busemeyer, 2009; Jahn, 2006).

\section{Political integration}

The hypotheses about the political dimension of European integration are based on the idea that political integration in the form of 'negative integration' (Scharpf, 
1999) puts pressure on national welfare states, compromising their potential to reduce income inequalities (Brady, 2005; Smeeding, 2005). In particular, we can think of two mechanisms: The constraining effects of the Economic and Monetary Union (EMU) and the dominance of the market liberalization agenda in EU policy-making.

Effects of the EMU. The impact of EMU—often described as the 'biggest step in European integration' (Martin and Ross, 2004b: 2) - could be an important factor delimiting welfare state spending (Korpi, 2003; Martin, 2004; Rhodes, 1996). As is well known, member states are obliged to meet the Maastricht convergence criteria before entering the EMU. The Stability and Growth Pact (SGP), which entered into force in 1998, is supposed to guarantee the compliance of member states with the fiscal policy requirements of the Maastricht criteria after the start of EMU. In December 2011, the so-called Sixpack reformed the SGP and tightened its regulations considerably (Leuffen et al., 2012: 149-151). Even though the current economic crisis has led to a temporary relaxation of these requirements, EMU-induced fiscal pressure presents the member states with formidable problems and sometimes even forces them to curtail public spending (Martin and Ross, 2004a). On top of that, some contend that the European Central Bank's (ECB) dedication to price stability — defined as its 'primary objective' (Martin and Ross, 2004b: 8) —dampens economic growth and keeps unemployment levels high (Korpi, 2003; Martin, 2004). If this were the case, the combined effects of the Maastricht convergence criteria and the ECB's anti-inflation policy would pose a severe threat to the welfare state's financial viability.

In short, the causal mechanism that links political integration via membership in the EMU to inequality runs via national fiscal policies. Compared to nonmembers, EMU members are obliged to follow stricter budgetary rules, which delimit their ability to counteract economic crises with higher levels of social spending. Even though the degree to which welfare states contribute to mitigating inequality depends on their respective institutional design, there is sound evidence that post-tax and -transfer levels of inequality are on average lower in more generous welfare states, whereas generosity does not necessarily have a strong impact on prefisc inequality (Bradley et al., 2003: 218-221). As a consequence, we should observe a negative association between EMU membership and levels of welfare state generosity as well as between membership and inequality in disposable (posttax and -transfer) income. If the EMU reduces the ability of member states to enact more accommodating fiscal and social policies, this will in the end contribute to higher levels of inequality.

Market liberalization agenda. Political integration at the European level has also promoted a course of liberalization in regulatory policies. Scholars have frequently referred to this phenomenon as an asymmetry between 'negative integration', i.e. the removal of trade barriers and market regulations, and 'positive integration', i.e. social regulations that correct market failures (Pollack, 2005; Rhodes, 1996; 
Scharpf, 1996, 1999). Scharpf (1999) identifies different actors as the root cause of this development. On the one hand, negative integration has been mainly driven by the European Commission and the European Court of Justice (ECJ), which both have been able to gradually expand their competences at the cost of member states (Scharpf, 1999: 50-62). On the other hand, positive integration largely depends on high levels of agreement and coordination among governments. However, due to ideological, economic, and institutional differences, agreement is extremely difficult to achieve and that is why social policy continues to be nationally determined (Scharpf, 1999: 71-83). Advancing political integration has thus enabled actors at the European level to promote 'a neoliberal program' (Kosonen, 1995: 104) supporting competition and deregulation of labor markets. Recent work by Höpner and Schäfer (2012) points out that political as well as 'judicial' integration via the ECJ has promoted a kind of European integration that is much more market oriented compared to integration in the pre-EMU era.

On this background, we argue that active opposition, i.e. noncompliance, with EU law may in certain cases be a politically motivated decision reflecting 'opposition through the backdoor' against a 'neoliberal' approach in economic policymaking (cf. Thomson, 2010; Thomson et al., 2007). This is partly at odds with existing literature on compliance with EU law (e.g. Falkner et al., 2007) that emphasizes the lack of bureaucratic capacities in some countries, in particular in Southern Europe, as an important factor explaining why compliance with EU law is higher in some member states than in others. From our perspective, noncompliance could be an active choice by domestic policy-makers to not implement policies that would promote the Single Market agenda against the opposition of domestic political actors. This would imply that higher levels of political integration in the form of a lower degree of noncompliance should go along with a higher level of inequality. If and when domestic actors are successful in blocking the implementation of market-enforcing integration, existing welfare state arrangements should be more protected and, therefore, contribute to lower levels of inequality.

Empirically, this link is hard to verify, in particular in a quantitative setting. First of all, one would need to distinguish between EU policies and ECJ decisions that are clearly promoting the Single Market agenda and those that do not. The indicator of European integration used in this paper (for details, see below) provides us with a partial, though imperfect solution to this problem. Still, quantitative analyses need to be complemented with case studies as is done in Höpner and Schäfer (2012). From a different, more empirical perspective, finding evidence in favor of a positive association between a higher degree of compliance with EU law and inequality despite the lack of a strong indicator would support the generalizability of some arguments made in the case-oriented literature.

A second and related argument as to why compliance with EU law could contribute to higher levels of inequality builds on the logic of the previous argument. Yet, instead of thinking in terms of noncompliance as a sign of opposition to the Single Market agenda, we could conceive of compliance as a supporting 
factor in promoting this agenda in the domestic context. Domestic policy-makers potentially faced with opposition from voters against welfare state retrenchment, deregulation, and liberalization could use the EU level as an instrument of blame avoidance, enabling them to promote these approaches much more effectively (Pierson, 2006; Scharpf, 1999). Moravcsik (1994: 24) states this most clearly: 'When things go badly, a technocratic Commission receives the blame; when things go well, national leaders claim the credit'. Put differently, national governments can convey the impression that if they were free of European constraints, they would act in a more welfare-friendly manner. Hence, in addition to the direct effects of market liberalizing policies, political integration may facilitate retrenchment indirectly by allowing domestic policy-makers to resort to politics of blame avoidance.

\section{Summary and hypotheses}

In sum, there are good reasons to expect the process of European integration to have consequences in terms of income inequality above and beyond the impact of economic globalization as such. To clarify, our focus is on inequality after taxes and transfers (inequality in disposable income). Partly this is motivated by practical concerns (see below), but more importantly, our theory centers on the impact of European integration on member states' ability to intervene and counteract market trends in inequality.

Our first hypothesis is that there is a positive association between economic integration and higher levels of inequality, because the former increases the price elasticity of the demand for labor, weakens the bargaining power of unions, and promotes a race to the bottom in terms of taxes and public spending. Due to limitations of the dataset we are using, it is not entirely possible to disentangle these different mechanisms properly. Instead, we take them as indicating that economic integration matters in different, but complementary ways.

Our second set of hypotheses relates to the impact of political integration. Political integration has two dimensions of relevance for the political economy of inequality. First, we expect that institutional participation is associated with higher levels of inequality because the stability criteria of the EMU impose concrete constraints on the budgetary politics and policies of member states, compromising their ability to counteract economic crises with higher levels of social spending. Second, the Single Market agenda advanced by EU institutions promotes the liberalization and deregulation of markets, which can be expected to lead to higher levels of inequality. Domestic opposition to this Single Market agenda might lead to a higher degree of noncompliance, i.e. lower levels of political integration. Furthermore, domestic actors supporting this agenda might receive additional political support by engaging in blame avoidance. Therefore, we expect to find a positive relation between the level of political integration and income inequality. 


\section{Empirical analysis}

\section{Measuring European integration}

To measure differences in integration, this study makes use of a newly developed index that captures political and economic indicators of European integration (König and Ohr, 2013). The index consists of 25 items grouped into four dimensions, which contribute with different weights to the overall index: (a) Single Market, (b) Homogeneity, (c) Symmetry, and (d) Conformity.

The first dimension of this index-Single Market - can be regarded as an indicator of economic integration, whereas the last relates to political integration. More specifically, the first dimension, the degree of market relations in the single market, is measured by the sum of a country's intra-EU imports and exports as a percentage of GDP, and as a percentage of its total sum of imports and exports. The indicator of political integration-Conformity - combines information on the member states' institutional participation in the Schengen area and membership in the EMU (Conformity participation) as well as compliance with EU law by counting infringement proceedings of the European Commission and ECJ verdicts in sectors like environment, social policy, and harmonization of legislation (Conformity_compliance). The index is coded in such a way that higher values indicate a higher degree of political integration (i.e. less infringement proceedings, for example). Most importantly for our purposes, the compliance indicator measures, among other things, the degree of compliance with ECJ verdicts in the field of the Single Market. Compared to the other areas of compliance, compliance with ECJ verdicts related to the Single Market receives the highest weight in the construction of this subindex. Assuming that noncompliance in the fields other than the Single Market is related to other factors such as bureaucratic capacities, the compliance indicator can be regarded as a rough proxy to measure the extent to which a particular member state complies with the Single Market agenda. Of course, this is a very rough approximation, but unfortunately, the subindices used to construct the compliance indicator are not available publicly. As for the remaining dimensions, Homogeneity and Symmetry (for detailed information, see König and Ohr, 2013), we include these indicators as control variables in some models without any concrete theoretical expectations on the direction of their impact.

The EU-Index covers $14^{1}$ of those 15 member states, which entered the EU up to and including 1995. König and Ohr (2013: 1079) exclude the case of Luxembourg, arguing that it contains many extreme values. The observation period starts with the formation of the EMU in 1999 and ends in 2010. For ease of comparability, the data are normalized to a scale ranging from 0 to 100 , where 100 represents maximal integration. The 25 normalized indicators are weighted on the basis of a principal component analysis. The EU-Index increased in all but one country (Spain), most strongly in Finland. The values of Austria, Belgium, Denmark, Germany, Greece, and Italy also increased by about 10 points, respectively. This general trend 


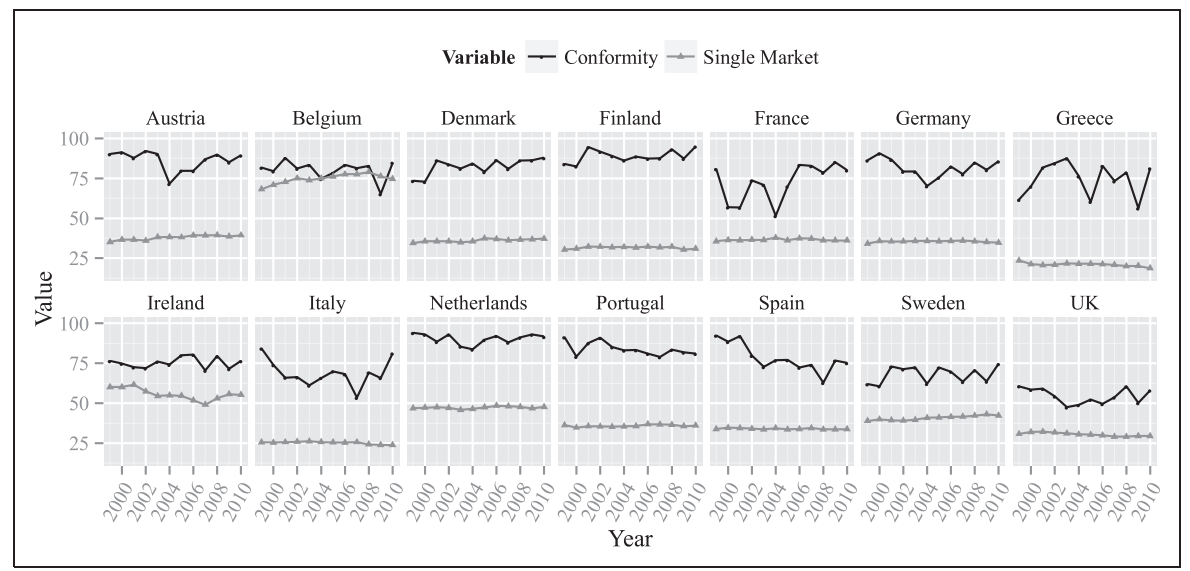

Figure I. Conformity and Single Market, 1999-20I0.

becomes explicit in the EU-14 average. Starting at a value of roughly 52 in 1999, the average EU-Index rose to almost 60 in 2010.

Figure 1 depicts trends for the two theoretically most interesting subindices, Single Market and Conformity. We see that the economic dimension does not show much variation over time. Variation between the countries is somewhat more pronounced, with Belgium, Ireland, Netherlands, and Sweden exhibiting above-average levels of market integration. For 2010, the index values range from 18.75 (Greece) to 74.62 (Belgium). The political dimension, on the other hand, depicts considerably more overtime variation within each country. Although the EU-14 average remains roughly constant at the 80 points level, the individual panels indicate that the variance of political integration is fairly high. Given that institutional participation is rather stable (changes can be observed in Denmark, Finland, Greece, and Sweden), this variance is mainly due to varying compliance levels.

Since the total EU-Index has a clear positive trend, we might face problems of nonstationarity. However, we do not include the EU-Index as a whole in our regression analyses but only its subdimensions. The graphical examination (Figure 1) does not suggest that these data are trended. In addition, we conducted various unit root tests that confirmed this conjecture.

\section{Measuring economic inequality}

Compared to the notion of European integration, the literature on measuring economic inequality is much more developed. By economic inequality we mean the peripheral distribution of income within countries. The presumably most commonly used inequality measure is the Gini index, which measures the extent to which the actual distribution deviates from a perfectly equalized distribution. 
The coefficients range between zero (maximum equality) and one (maximum inequality).

In this study, we draw on data from the EU Statistics on Income and Living Conditions (EU-SILC) survey provided by Eurostat. We prefer to use these data instead of alternatives because data quality is likely to be higher in the case of the EU-SILC, given that the data are harmonized between EU member states. In particular, we include Gini coefficients of equivalized disposable household income for each of the EU-14 member states between 1999 and 2010. Figure 2 compares Gini coefficients for each country in the first and last year under observation. The countries are arranged according to the values of 2010 beginning with the highest. Overall, the EU-14's average Gini coefficient increased from 0.285 to 0.294 within a decade. The strongest surges can be observed in countries that exhibited low levels of inequality in the former period, such as Denmark, Germany, and Sweden. However, all three countries still show below-average levels of inequality. In 10 out of 14 member states, economic inequality in 2010 was higher than in 1999. Decreases could only be observed in Belgium, the Netherlands, Portugal, and Spain. A cross-country comparison reveals conspicuous cross-national differences. For 2010, the coefficients range from 0.241 (Sweden) to 0.339 (Spain).

An alternative approach to measure economic inequality is to compare relative (disposable) incomes at the top of the income distribution with incomes at the bottom. Eurostat provides an indicator of this kind. The income quintile share ratio ( $\mathrm{S} 80 / \mathrm{S} 20$ ratios) is a measure of the income of the person at the 80 th percentile in the distribution of incomes relative to the income of an individual at the 20th percentile. A higher value thus indicates a higher level of income dispersion. In the subsequent empirical analysis, we will use both measures of economic inequality.

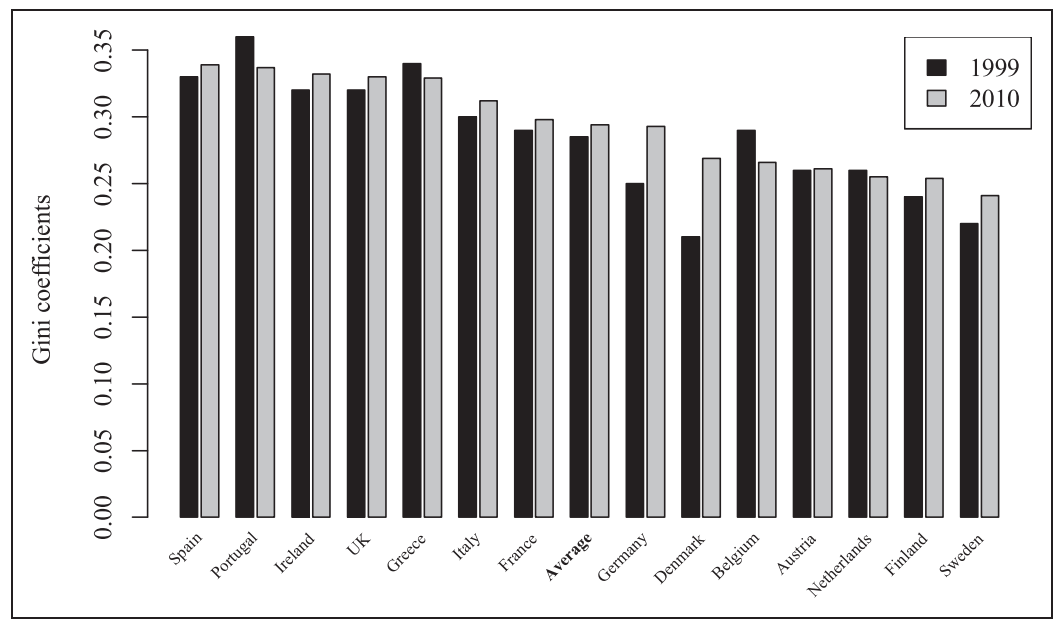

Figure 2. Gini coefficients, 1999/2010. 
To repeat, we focus on inequality in disposable, i.e. post-tax and -transfer income because our theory concerns the limited ability of EU member states to counteract market trends. Above and beyond that, European integration could have an effect on pretax inequality in the sense that more liberalized labor and product markets could be associated with higher levels of pretax wage dispersion. However, for the reasons mentioned above, we focus on the impact on postfisc inequality in the present case.

\section{Methods}

Our dataset includes 14 EU member states $(N=14)$ for the time period 1999-2010 $(T=12)$. This kind of data structure is referred to as time-series-cross-section (TSCS) data (Beck and Katz, 1995, 1996, 2011). Three potential violations of ordinary least squares assumptions are commonplace in the TSCS context (Plümper et al., 2005). First, errors may tend to correlate over different time periods (autocorrelation). Second, errors may have different variances across units (group-wise heteroskedasticity). Third, common exogenous shocks may cause the errors to be correlated across units (contemporaneous correlation of errors). To address these problems, Beck and Katz $(1995,1996)$ proposed two remedies. In order to deal with autocorrelated errors, they recommend including the lagged dependent variable (LDV) on the right-hand side of the regression equation. With regard to heteroskedasticity and contemporaneous correlated errors, they suggest using panel-corrected standard errors (PCSEs) that prevent a systematic underestimation of the true variance.

However, the application of the Beck and Katz method has become the object of criticism (e.g. Wilson and Butler, 2007). One common problem is that the LDV tends to be too restrictive, as it absorbs part of the explanatory power of other independent variables (Achen, 2000). Thus, an alternative method to model the serially correlated residuals is a first-order autoregression or AR(1) process

$$
\varepsilon_{i, t}=\rho \varepsilon_{i, t-1}+u_{t}
$$

where $\varepsilon_{i, t}$ is the residual for the $i$ th country at time $t, u_{t}$ is independent and identically distributed with mean 0 , and $\rho$ is the so-called autocorrelation parameter. In the subsequent analysis, the Prais-Winsten estimator is applied to transform the data as follows

$$
\begin{gathered}
Z_{i, t}^{*}=\sqrt{1-\hat{\rho} z_{i, 1}}, \quad \text { for } t=1 \\
Z_{i, t}^{*}=Z_{i, t}-\hat{\rho} Z_{i, t}, \quad \text { for } t=2, \ldots, T
\end{gathered}
$$

where $Z=x, y$. Hence, each value of $x$ and $y$ is corrected by the product of the value and the estimated coefficient $\rho$ of the AR(1) process. 
Given the rather short length of our panel, we prefer the AR(1) approach to the LDV method, since the LDV would further reduce the length of the time series. Furthermore, it is well known that the inclusion of an LDV suppresses the explanatory power of the other independent variables (Achen, 2000), and this effect is particularly severe when the panel is short and other explanatory variables change little over time as in our case. In order to control for group-wise heteroskedasticity and contemporaneous correlation of errors, the reported PraisWinsten models are used with PCSEs.

Another common problem is how to obtain consistent estimators in the presence of omitted variables. If the residuals are correlated within countries, some explanatory factor has been omitted, and the exclusion of this factor may bias the parameter estimates for the covariates included in the model (violation of the exogeneity assumption). Our solution to the problem of unobserved effects is the fixed-effects model (FEM), which estimates country-specific intercepts, that is it demeans all of the variables by their country-specific means.

The model may be formulated as

$$
y_{i, t}=\beta x_{i, t}+\alpha_{i}+\varepsilon_{i, t} ; \quad \varepsilon_{i, t}=\rho \varepsilon_{i, t-1}+u_{t}
$$

where $\alpha_{i}$ is the country-specific intercept, $y_{i, t}$ and $x_{i, t}$ are observations, and $\beta$ is a vector of coefficients. ${ }^{2}$

\section{Control variables}

In addition to our main explanatory variables related to European integration, we include the following control variables:

1. SingleMarket_squared: Beckfield (2005, 2006, 2009) provides empirical evidence for a nonlinear relationship between economic integration and income inequality. Thus, a quadratic transformation of SingleMarket enters the regression models.

2. TradeDen and Gov_Party: To assess whether the weakening of the labor force diminishes unions' bargaining power, we include trade union density (source: OECD Labour Force Statistics). The expected relationship with economic inequality is negative. Furthermore, we include a measure of government partisanship to take into account the impact of partisan politics (source: Armingeon et al., 2013). Left partisanship should be associated with lower levels of inequality.

3. Tax: To test the economic argument that a higher tax burden on labor is associated with an increase in economic inequality, we also include the tax rate on low wage earners (source: Structures of Earnings Survey, Eurostat). The estimated coefficient is hypothesized to be positive.

4. Unemployment and GDP_Growth: These variables capture the economic context. Unemployment is expected to be associated with higher levels of inequality 
(source: European Union Labour Force Survey, Eurostat), whereas higher GDP growth should depress inequality (source: Armingeon et al., 2013).

5. Soc_Tran: We include a measure of social transfers (source: Armingeon et al., 2013). Higher levels of transfers should be associated with lower levels of inequality.

6. Coord: The political economy literature on inequality (e.g. Pontusson et al., 2002) identifies wage bargaining centralization as an important negative determinant of wage inequality (source: Visser, 2013). Since we are using FEMs, the effect should be weak because this variable captures cross-national differences in wage bargaining institutions rather than changes over time.

7. Education: The percentage of the population having at least upper secondary education enters the models as a final control variable (source: European Union Labour Force Survey, Eurostat). The expected impact on economic inequality is negative.

\section{Results}

Tables 1 and 2 present the results of the Prais-Winsten FEMs with AR(1) disturbances and PCSEs. In each table, respectively, the first specification contains the political and economic dimensions of integration, the second adds the remaining subindices, the third includes our full battery of controls, and the fourth splits the Conformity variable into its two subdimensions: institutional participation and compliance with EU law. Furthermore, these models are applied to both inequality measures, with the models in Table 1 using the Gini index ${ }^{3}$ and the models in Table 2 the income quintile share ratios as dependent variable.

Our most important finding is that political integration in terms of institutional participation and compliance with EU law exhibits a consistently positive and statistically significant association with both inequality measures. In the case of the Gini measure, the coefficient estimate of political integration is positive and significant in all model specifications, and the magnitude of the effect is roughly constant as well. In case of the $\mathrm{S} 80 / \mathrm{S} 20$ ratios, the variable is not significantly different from zero in the first two model specifications but points in the expected direction. When we include the full battery of controls, however, Conformity turns significant at the .05 level.

As for the subdimensions of political integration, both participation and compliance show positive signs and reach common levels of statistical significance in the models with the Gini index (Table 1). Even though the coefficient for Conformity participation is not distinguishable from zero in Table 2, the results suggest that the effect of political integration is due to both institutional participation as well as compliance with EU law. We present similar estimates in the subsequent 'Robustness' section (see web appendix for details), where we find that indeed both dimensions are important when comparing different model specifications. 
Table I. Prais-Winsten FEMs with Gini index as dependent variable.

\begin{tabular}{|c|c|c|c|c|}
\hline & $\begin{array}{l}\text { (I) } \\
\text { Gini }\end{array}$ & $\begin{array}{l}(2) \\
\text { Gini }\end{array}$ & $\begin{array}{l}\text { (3) } \\
\text { Gini }\end{array}$ & $\begin{array}{l}\text { (4) } \\
\text { Gini }\end{array}$ \\
\hline SingleMarket & $\begin{array}{r}-0.050 \\
(0.064)\end{array}$ & $\begin{array}{r}-0.034 \\
(0.066)\end{array}$ & $\begin{array}{c}0.344 \\
(0.218)\end{array}$ & $\begin{array}{c}0.353^{*} \\
(0.214)\end{array}$ \\
\hline SingleMarket_squared & & & $\begin{array}{c}-0.004^{* *} \\
(0.002)\end{array}$ & $\begin{array}{c}-0.004 * * \\
(0.002)\end{array}$ \\
\hline Conformity & $\begin{array}{l}0.026 * * \\
(0.012)\end{array}$ & $\begin{array}{l}0.029 * * \\
(0.012)\end{array}$ & $\begin{array}{l}0.029 * * \\
(0.013)\end{array}$ & \\
\hline Conformity_participation & & & & $\begin{array}{l}0.025^{* * *} \\
(0.006)\end{array}$ \\
\hline Conformity_compliance & & & & $\begin{array}{c}0.016 * \\
(0.009)\end{array}$ \\
\hline Homogeneity & & $\begin{array}{c}-0.001 \\
(0.029)\end{array}$ & $\begin{array}{l}0.073 * * \\
(0.032)\end{array}$ & $\begin{array}{c}0.064^{*} \\
(0.033)\end{array}$ \\
\hline Symmetry & & $\begin{array}{c}0.010 * \\
(0.006)\end{array}$ & $\begin{array}{c}0.013 \\
(0.009)\end{array}$ & $\begin{array}{c}0.010 \\
(0.009)\end{array}$ \\
\hline TradeDen & & & $\begin{array}{c}-0.126 * \\
(0.069)\end{array}$ & $\begin{array}{r}-0.114^{*} \\
(0.066)\end{array}$ \\
\hline Tax & & & $\begin{array}{r}-0.036 \\
(0.042)\end{array}$ & $\begin{array}{r}-0.031 \\
(0.042)\end{array}$ \\
\hline Unemployment & & & $\begin{array}{c}0.058 \\
(0.059)\end{array}$ & $\begin{array}{c}0.082 \\
(0.066)\end{array}$ \\
\hline Soc_Tran & & & $\begin{array}{c}-0.298 * * \\
(0.124)\end{array}$ & $\begin{array}{c}-0.304 * * \\
(0.129)\end{array}$ \\
\hline Gov_Party & & & $\begin{array}{r}-0.000 \\
(0.064)\end{array}$ & $\begin{array}{c}0.013 \\
(0.067)\end{array}$ \\
\hline GDP_Growth & & & $\begin{array}{r}-0.040 \\
(0.036)\end{array}$ & $\begin{array}{r}-0.043 \\
(0.032)\end{array}$ \\
\hline Coord & & & $\begin{array}{r}-0.050 \\
(0.157)\end{array}$ & $\begin{array}{r}-0.097 \\
(0.154)\end{array}$ \\
\hline Education & & & $\begin{array}{r}-0.052^{*} \\
(0.029)\end{array}$ & $\begin{array}{c}-0.056 * * \\
(0.028)\end{array}$ \\
\hline Constant & $\begin{array}{l}25.400 * * * \\
(2.776)\end{array}$ & $\begin{array}{c}24.229 * * * \\
(3.919)\end{array}$ & $\begin{array}{l}24.554 * * * \\
(8.848)\end{array}$ & $\begin{array}{l}23.727^{* * *} \\
(8.418)\end{array}$ \\
\hline Observations & $|5|$ & $|5|$ & 144 & 144 \\
\hline $\mathrm{R}^{2}$ & 0.993 & 0.991 & 0.993 & 0.993 \\
\hline Number of countries & 14 & 14 & 14 & 14 \\
\hline Country FE & YES & YES & YES & YES \\
\hline
\end{tabular}

Panel-corrected standard errors in parentheses.

$* * * \mathrm{p}<0.01$, ** $\mathrm{p}<0.05$, *p $<0.1$. 
Table 2. Prais-Winsten FEMs with S80/S20 ratios as dependent variable.

\begin{tabular}{|c|c|c|c|c|}
\hline & $\begin{array}{c}(\mathrm{I}) \\
\text { Ratio }\end{array}$ & $\begin{array}{c}(2) \\
\text { Ratio }\end{array}$ & $\begin{array}{c}(3) \\
\text { Ratio }\end{array}$ & $\begin{array}{c}(4) \\
\text { Ratio }\end{array}$ \\
\hline SingleMarket & $\begin{array}{c}0.001 \\
(0.015)\end{array}$ & $\begin{array}{c}0.003 \\
(0.0149)\end{array}$ & $\begin{array}{r}-0.009 \\
(0.046)\end{array}$ & $\begin{array}{r}-0.009 \\
(0.046)\end{array}$ \\
\hline SingleMarket_squared & & & $\begin{array}{r}-0.0007 \\
(0.0004)\end{array}$ & $\begin{array}{r}-0.0007 \\
(0.0004)\end{array}$ \\
\hline Conformity & $\begin{array}{c}0.005 \\
(0.003)\end{array}$ & $\begin{array}{c}0.005 \\
(0.003)\end{array}$ & $\begin{array}{l}0.006 * * \\
(0.003)\end{array}$ & \\
\hline Conformity_participation & & & & $\begin{array}{c}0.003 \\
(0.002)\end{array}$ \\
\hline Conformity_compliance & & & & $\begin{array}{c}0.004 * \\
(0.002)\end{array}$ \\
\hline Homogeneity & & $\begin{array}{r}-0.004 \\
(0.006)\end{array}$ & $\begin{array}{c}0.012 * \\
(0.007)\end{array}$ & $\begin{array}{c}0.012 \\
(0.007)\end{array}$ \\
\hline Symmetry & & $\begin{array}{c}0.002 \\
(0.001)\end{array}$ & $\begin{array}{c}0.001 \\
(0.002)\end{array}$ & $\begin{array}{c}0.001 \\
(0.002)\end{array}$ \\
\hline TradeDen & & & $\begin{array}{c}-0.029 * \\
(0.016)\end{array}$ & $\begin{array}{c}-0.028 * \\
(0.016)\end{array}$ \\
\hline Tax & & & $\begin{array}{c}0.000 \\
(0.010)\end{array}$ & $\begin{array}{c}0.000 \\
(0.010)\end{array}$ \\
\hline Unemployment & & & $\begin{array}{l}0.045^{* *} \\
(0.019)\end{array}$ & $\begin{array}{l}0.046 * * \\
(0.020)\end{array}$ \\
\hline Soc_Tran & & & $\begin{array}{c}-0.112^{* * *} \\
(0.033)\end{array}$ & $\begin{array}{c}-0.112^{* * * *} \\
(0.033)\end{array}$ \\
\hline Gov_Party & & & $\begin{array}{r}-0.006 \\
(0.020)\end{array}$ & $\begin{array}{r}-0.006 \\
(0.020)\end{array}$ \\
\hline GDP_Growth & & & $\begin{array}{c}-0.020 * * \\
(0.009)\end{array}$ & $\begin{array}{c}-0.020 * * \\
(0.009)\end{array}$ \\
\hline Coord & & & $\begin{array}{r}-0.033 \\
(0.030)\end{array}$ & $\begin{array}{r}-0.035 \\
(0.032)\end{array}$ \\
\hline Education & & & $\begin{array}{r}-0.006 \\
(0.008)\end{array}$ & $\begin{array}{r}-0.006 \\
(0.008)\end{array}$ \\
\hline Constant & $\begin{array}{l}3.238 * * * \\
(0.682)\end{array}$ & $\begin{array}{l}3.454 * * * \\
(0.870)\end{array}$ & $\begin{array}{l}6.016 * * * \\
(1.784)\end{array}$ & $\begin{array}{l}6.002^{\text {*** }} \\
(1.781)\end{array}$ \\
\hline Observations & 153 & 153 & 146 & 146 \\
\hline $\mathrm{R}^{2}$ & 0.983 & 0.981 & 0.988 & 0.988 \\
\hline Number of countries & 14 & 14 & 14 & 14 \\
\hline Country FE & YES & YES & YES & YES \\
\hline
\end{tabular}

Panel-corrected standard errors in parentheses.

$*_{* *} \mathrm{p}<0.01, *^{*} \mathrm{p}<0.05$, * $\mathrm{p}<0.1$. 
The magnitude of the effect of political integration on inequality is sizable: Simulating an increase in political integration of one standard deviation is predicted to be associated with an increase in inequality of 0.327 in the Gini index. This is about $8.4 \%$ of the standard deviation of the Gini index. Using the income quintile ratio instead, the predicted effect would be 0.072 . This is about $7 \%$ of one standard deviation of our alternative measure of inequality.

With regard to the economic dimension of integration, we find empirical support for a curvilinear relationship with the Gini index. The squared term is significantly negative, and the Single Market variable flips its sign and becomes - in line with our theoretical expectations - positive. While this positive coefficient is not statistically significant in model 3, it turns significant at the .05 level once we include the subindices of the political integration dimension (model 4). The effect is also very substantial: A simulated increase in economic integration from 30 (roughly the level of the United Kingdom in 2010) to 75 (roughly the level of Belgium in 2010 ) is associated with an increase of about 16 points in the recoded Gini index. This is more than four times its standard deviation.

These results cannot be replicated for models, which use the income quintile share ratios as dependent variable. Overall we find fewer significant estimates in these models than in the models using the Gini index (see also the 'Robustness' section). However, we consider the results of the Gini index as more important for the following reasons. First, quintile ratio measures, by their very nature, ignore information about incomes other than the quintiles selected (Jenkins and van Kerm, 2009). Second and related to the first point, quintile ratio indices do not satisfy the Pigou-Dalton principle of transfers, i.e. that a mean-preserving income transfer from a richer person to someone poorer should always decrease inequality (Atkinson and Brandolini, 2015).

The control variables perform generally as expected. While higher levels of trade union density, social transfers, GDP growth, and education are related to lower levels of inequality, higher levels of unemployment correspond to an increase in inequality. As for the other dimensions of the EU-Index, homogeneity is also positively associated with inequality in some of the models (models 3 and 4 using the Gini index and model 3 using the S80/S20 ratios). Although it is not possible to show this directly, this could indicate an indirect effect of EMU membership. The indicator of homogeneity measures whether economic factors converge in the observed countries. The indicators used to construct this index such as purchasing power standards, long-term interest rates, or public debt ratio are precisely those we expect to convergence as a consequence of the Maastricht convergence criteria, which in turn are closely related to EMU membership.

We argue above that the causal mechanism linking political integration to inequality runs mainly through national fiscal policies. More specifically, we expect institutional membership to constrain governments' ability to spend. Table 3 thus tries to answer the question whether European integration is a significant determinant of spending levels. All models contain the same battery of controls as previously used (excluding social transfers). Focusing on quantities of 
Table 3. Relationship between European integration and spending levels.

\begin{tabular}{lccc}
\hline & $(\mathrm{I})$ & $(2)$ & $(3)$ \\
& Soc_Tran & Soc_Protect & Pub_Exp \\
\hline SingleMarket & $-0.388^{* * * *}$ & $-0.06 \mathrm{I}$ & -0.463 \\
& $(0.13 \mathrm{I})$ & $(0.148)$ & $(0.305)$ \\
SingleMarket_squared & $0.002^{* *}$ & -0.0005 & 0.002 \\
& $(0.00 \mathrm{I})$ & $(0.0012)$ & $(0.003)$ \\
Conformity_participation & -0.003 & $-0.020^{* *}$ & $-0.053^{* * *}$ \\
& $(0.006)$ & $(0.008)$ & $(0.015)$ \\
Conformity_compliance & 0.005 & 0.002 & $0.01 \mathrm{I}$ \\
& $(0.004)$ & $(0.005)$ & $(0.010)$ \\
Constant & $16.325^{* * *}$ & $16.694 * * *$ & $32.535^{* * *}$ \\
& $(4.316)$ & $(5.622)$ & $(9.55 \mathrm{I})$ \\
Observations & $16 \mathrm{I}$ & $16 \mathrm{I}$ & $16 \mathrm{I}$ \\
$\mathrm{R}^{2}$ & $0.99 \mathrm{I}$ & 0.995 & 0.993 \\
Number of countries & $\mid 4$ & 14 & 14 \\
Country FE & YES & YES & YES \\
Controls & YES & YES & YES \\
\hline
\end{tabular}

Panel-corrected standard errors in parentheses.

$*_{* *} \mathrm{p}<0.01, *^{*} \mathrm{p}<0.05, *_{\mathrm{p}}<0.1$.

interest, we only show the results for the relevant integration indicators. Social transfer levels serve as the dependent variable in model 1. The estimates suggest that higher levels of economic integration are associated with lower levels of transfers. With regard to the variable Conformity_participation, the coefficient points in the expected direction, but the estimate is not statistically significant. Model 2 uses public social protection spending as percentage of GDP (Soc_Protect, source: Eurostat) as regressand. Now, institutional membership exhibits a significantly negative relationship with spending levels. The estimated coefficient of SingleMarket is still negative but no longer significantly different from zero. We obtain similar results when we regress total public expenditure as percentage of GDP (Pub_Exp, source: Eurostat) on our explanatory variables. A simulated increase from no institutional participation (e.g. the United Kingdom) to full EMU membership (e.g. the Netherlands) is accompanied with a decrease in social protection spending by roughly two percentage points of GDP and five percentage points of GDP in total public expenditure, respectively. These findings suggest that our proposed mechanism does survive empirical scrutiny. Yet, one has to treat the results with some caution, since only four (Denmark, Finland, Greece, and Sweden) of the 14 countries exhibit within-country variation in institutional participation. 


\section{Robustness}

In this section we test the robustness of our findings. The sensitivity of TSCS analyses to alternative specifications is a well-known problem. Wilson and Butler (2007) argue that there is generally little guidance for researchers on what type of specification to employ. They then go on to provide a list of dynamic models that are often applied with TSCS data. The various specifications differ with regard to their precise implications, but they share their trend-eliminating, dynamic nature, and the insight that effects may develop differently over time. Both characteristics seem to be useful in our context. First, we observe a general trend of rising inequality. Second, it can be assumed that the impact of European integration is not felt immediately on the inequality variable but rather distributed over time. We thus estimate the following models and compare the results (see Table A2 of the web appendix) to our previous findings: first difference, lag, LDV, and error correction.

In Table A2 in the web appendix, we present the coefficients for the variables of greatest interest, i.e. SingleMarket, SingleMarket_squared, Conformity_participation, and Conformity_compliance. These variables enter the analysis in the first models (1 and 4), then the remaining subindices of the EU-Index are added (models 2 and 5), and finally we include all other controls (models 3 and 6). The control variables perform in accordance with our expectations.

As for our main independent variables, the results are largely consistent with our earlier findings. The political integration indicators are positive in all model specifications and often reach conventional levels of statistical significance. The models that use the Gini index (models 1-3) again show more significant estimates. Looking at these models, the institutional dimension of political integration exhibits a significantly positive association with inequality in all but one model (LDV model 3). Although the effect of compliance with EU law is suppressed in the demanding LDV and error-correction models, the other model specifications corroborate the results of Table 1. As for the economic dimension, the estimates are not entirely robust. All regression coefficients show the correct sign, but only some are significantly different from zero.

Although we find fewer significant effects in the quintile share ratio models (models 4-6), the results confirm our previous findings indicating that political integration affects inequality through both institutional participation and compliance with EU law. The consistency of these estimates strengthens our belief that the relationship between political integration and inequality is nonrandom and positive. On the other hand, none of the SingleMarket coefficients are statistically significant. However, different from Table 2, all but one estimate (LDV model 3) point in the theorized direction.

\section{Conclusion}

This paper has analyzed the association between European integration and differences in socioeconomic inequality in countries of the EU. Relying on a new dataset 
that measures the extent of European integration across different dimensions, we found evidence for a positive and statistically significant relationship between political integration in terms of institutional (EMU) membership as well as compliance with EU law and inequality. This association is more robust than the effect of economic integration. Our results confirm Scharpf's (1999) notion of the dominance of negative over positive integration: Membership in EU institutions tends to go along with higher levels of inequality.

Of course, this conclusion should be treated with caution: Even though we control for a large number of potential determinants, our analysis cannot prove the existence of a causal relationship between political integration and inequality in the strict sense, since regression analysis merely shows correlations. Furthermore, our research design focuses on the impact of differences in integration within the EU. A different research design (for instance see Beckfield, 2005, 2006, 2009) could compare differences in inequality trends between member states of the EU and nonmember states. From a broader perspective, European countries are commonly characterized as exhibiting lower levels of income inequality, in particular compared to liberal market economies such as the United States (Pontusson, 2005). Our findings, however, suggest that the process of European integration could in the long term contribute to transforming European countries toward a more liberal variety of capitalism.

Thus, the implications of this article are straightforward: Those hoping that EU policies could potentially balance out the negative side effects of European and global economic integration on the viability of national welfare states will be disappointed. The current institutional and political setup of the EU certainly does not seem to be an effective counterweight against the ubiquitous trends toward rising inequality. Here, it needs to be emphasized that although we treat them as separate dimensions of European integration, political and economic integration are connected. Politically driven liberalization is in fact aimed at promoting economic integration, and the creation of an integrated Single Market most likely also empowers political coalitions in support of further liberalization. As is shown in a recent contribution by Garry and Tilley (2015), changes in macro-level economic contexts (inequality and the extent of state ownership in their case) also affect support for continued European integration at the level of individual voters. Nevertheless and within the confines of our research design, this paper aimed at partly disentangling these effects in order to get a better understanding of the driving forces of inequality in the EU.

\section{Notes}

1. Austria, Belgium, Denmark, Finland, France, Germany, Greece, Ireland, Italy, Netherlands, Portugal, Spain, Sweden, UK.

2. The consistency of the FEM comes at costs, as it removes all between-country variation from the data. The Hausman test, however, rejects the application of more efficient random effects models. A FEM specification is also more in line with our theoretical 
expectations, which aim at determining the contribution of changes in economic and political integration within countries on changes in inequality.

3. Multiplied by 100 in order to improve readability.

\section{References}

Achen CF (2000) Why lagged dependent variables can suppress the explanatory power of other independent variables. Paper presented at the annual meeting of the political methodology section of the American Political Science Association, University of California, Los Angeles, 20-22 July 2000. Available at: http://www.polmeth.wustl.edu/media/Paper/ achen00.pdf (accessed 30 June 2013).

Alderson AS and Nielsen F (2002) Globalization and the great U-turn: Income inequality trends in 16 OECD countries. American Journal of Sociology 107(5): 1244-1299.

Armingeon K, Engler S, Potolidis P, et al. (2013) Comparative Political Data Set I 1960 2011. Bern: Institute of Political Science, University of Bern.

Atkinson AB and Brandolini A (2015) Unveiling the ethics behind inequality measurement: Dalton's contribution to economics. Economic Journal 125(583): 209-234.

Beck N and Katz JN (1995) What to do (and not to do) with time-series cross-section data. American Political Science Review 89(3): 634-647.

Beck N and Katz JN (1996) Nuisance vs. substance: Specifying and estimating time-seriescross-section models. Political Analysis 6(1): 1-36.

Beck N and Katz JN (2011) Modeling dynamics in time-series-cross-section political economy data. Annual Review of Political Science 14(1): 331-352.

Beckfield J (2005) The consequences of regional political and economic integration for inequality and the welfare state in Western Europe. $\mathrm{PhD}$ Thesis, Indiana University, USA.

Beckfield J (2006) European integration and income inequality. American Sociological Review 71(6): 964-985.

Beckfield J (2009) Remapping inequality in Europe: The net effect of regional integration on total income inequality in the European Union. International Journal of Comparative Sociology 50(5-6): 486-509.

Bradley D, Huber E, Moller S, et al. (2003) Distribution and redistribution in postindustrial democracies. World Politics 55(2): 193-228.

Brady D (2005) The welfare state and relative poverty in rich western democracies, 1967-1997. Social Forces 83(4): 1329-1364.

Burgoon B (2009) Social Nation and Social Europe: Support for national and supranational welfare compensation in Europe. European Union Politics 10(4): 427-455.

Busemeyer MR (2009) From myth to reality: Globalization and public spending in OECD countries revisited. European Journal of Political Research 48(4): 455-482.

Busemeyer MR (2015) Skills and Inequality: The Political Economy of Education and Training Reforms in Western Welfare States. Cambridge/New York: Cambridge University Press.

Caporaso JA (1976) The external consequences of regional integration for pan-European relations: Inequality, dependence, polarization, and symmetry. International Studies Quarterly 20(3): 341-392.

Dreher A and Gaston N (2007) Has globalisation really had no effect on unions? KYKLOS 60(2): 165-186.

Dreher A and Gaston N (2008) Has globalization increased inequality? Review of International Economics 16(3): 516-536. 
European Union (2013) Summaries of EU legislation: Internal market. Available at: http:// europa.eu/legislation_summaries/internal_market/index_en.htm (accessed 3 June 2013).

Falkner G, Hartlapp M and Treib O (2007) Worlds of compliance: Why leading approaches to European implementation are only 'sometimes-true theories'. European Journal of Political Research 46(3): 395-476.

Garry J and Tilley J (2015) Inequality, state ownership and the European Union: How economic context and economic ideology shape support for the European Union. European Union Politics 16(1): 139-154.

Höpner M and Schäfer A (2012) Embeddedness and regional integration: Waiting for Polanyi in a Hayekian setting. International Organization 66(3): 429-455.

Iversen T and Soskice D (2006) Electoral institutions and the politics of coalitions: Why some democracies redistribute more than others. American Political Science Review 100(2): $165-181$.

Iversen T and Soskice D (2009) Distribution and redistribution: The shadow of the nineteenth century. World Politics 61(3): 438-486.

Jahn D (2006) Globalization as 'Galton's problem': The missing link in the analysis of diffusion patterns in welfare state development. International Organization 60(2): 401-431.

Jenkins SP and Van Kerm P (2009) The measurement of economic inequality. In: Salverda W, Nolan B and Smeeding TM (eds) The Oxford Handbook of Economic Inequality. Oxford: Oxford University Press, pp. 40-69.

König J and Ohr R (2013) Different efforts in European economic integration: Implications of the EU-Index. Journal of Common Market Studies 51(6): 1074-1090.

Korpi W (2003) Welfare-state regress in Western Europe: Politics, institutions, globalization, and Europeanization. Annual Review of Sociology 29(1): 589-609.

Kosonen P (1995) European welfare state models: Converging trends. International Journal of Sociology 25(1): 81-110.

Leuffen D, Rittberger B and Schimmelfennig F (2012) Differentiated Integration: Explaining Variation in the European Union. Basingstoke: Palgrave Macmillan.

Mahler VA (2004) Economic globalization, domestic politics, and income inequality in the developed countries a cross-national study. Comparative Political Studies 37(9): 1025-1053.

Martin A (2004) The EMU macroeconomic policy regime and the European social model. In: Martin A and Ross G (eds) Euros and European: Monetary Integration and the European Social Model. Cambridge: Cambridge University Press, pp. 20-50.

Martin A and Ross G (2004a) Introduction: EMU and the European social model. In: Martin A and Ross G (eds) Euros and European: Monetary Integration and the European Social Model. Cambridge: Cambridge University Press, pp. 1-19.

Martin A and Ross G (2004b) Conclusions. In: Martin A and Ross G (eds) Euros and European: Monetary Integration and the European Social Model. Cambridge: Cambridge University Press, pp. 309-330.

Moravcsik A (1994) Why the European Union strengthens the state: Domestic politics and international cooperation. Center for European Studies Working Papers Series 52. Available at: https://ces.fas.harvard.edu/files/working_papers/CES_WP52.pdf (accessed 24 June 2013).

Pierson P (2006) The new politics of the welfare state. World Politics 48(2): 143-179.

Plümper T, Tröger VE and Manow P (2005) Panel data analysis in comparative politics: Linking method to theory. European Journal of Political Research 44(2): 327-354. 
Pollack MA (2005) Theorizing the European Union: International organization, domestic polity, or experiment in new governance? Annual Review of Political Science 8(1): 357-398.

Pontusson J (2005) Inequality and Prosperity: Social Europe vs. Liberal America. Ithaca: Cornell University Press.

Pontusson J, Rueda D and Way CR (2002) Comparative political economy of wage distribution: The role of partisanship and labour market institutions. British Journal of Political Science 32(2): 281-308.

Rhodes M (1996) Globalization and west European welfare states: A critical review of recent debates. Journal of European Social Policy 6(4): 305-327.

Rueda D and Pontusson J (2000) Wage inequality and varieties of capitalism. World Politics 52(3): 350-383.

Scharpf FW (1996) Negative and positive integration in the political economy of European welfare state. In: Marks G, Scharpf FW, Schmitter PC, et al. (eds) Governance in the European Union. London: SAGE Publications, pp. 15-39.

Scharpf FW (1999) Governing in Europe: Effective and Democratic? Oxford: Oxford University Press.

Scharpf FW (2002) The European social model: Coping with the challenges of diversity. Journal of Common Market Studies 40(4): 645-670.

Scheve K and Slaugther MJ (2004) Economic insecurity and the globalization of production. American Journal of Political Science 48(4): 662-674.

Smeeding TM (2005) Public policy, economic inequality, and poverty: The United States in comparative perspective. Social Science Quarterly 86(Issue Supplement s1): 955-983.

Solga H (2014) Education, economic inequality and the promises of the social investment state. Socio-economic Review 12(2): 269-297.

Streeck W and Schmitter PC (1991) From national corporatism to transnational pluralism: Organized interests in the Single European Market. Politics and Society 19(2): 133-164.

Thomson R (2010) Opposition through the back door in the transposition of EU directives. European Union Politics 11(4): 577-596.

Thomson R, Torenvlied R and Arregui J (2007) The paradox of compliance. Infringements and delays in transposing EU directives. British Journal of Political Science 37(4): 685-709.

Visser J (2013) The ICTWSS Database: Institutional Characteristics of Trade Unions, Wage Setting, State Intervention and Social Pacts in 34 Countries Between 1960 and 2011. Amsterdam: Amsterdam Institute of Advanced Labour Studies.

Wallerstein M (1999) Wage-setting institutions and pay inequality in advanced industrial societies. American Journal of Political Science 43(3): 649-680.

Wilson SE and Butler DM (2007) A lot more to do: The sensitivity of time-series crosssection analyses to simple alternative specifications. Political Analysis 15(3): 101-123. 